\title{
Terrazzo floor from the Jewish Historical Institute in Warsaw - mineralogical characterization, conservation and impact of fire
}

\author{
Wojciech Bartz' ${ }^{1}$ Jacek Martusewicz
}

'University of Wrocław, Institute of Geological Sciences, pl. M. Borna 9, 50-204 Wrocław I

${ }^{2}$ Academy of Fine Arts in Warsaw, Faculty of Conservation and Restoration of Works of Art, ul. Wybrzeże Kościuszkowskie 37, 00-379 Warszawa;

Record

Mineralogical changes in the composition of historic terrazzo records thermal impact of fire.

Abstract

Samples of historical terrazzo floor from the Jewish Historical Institute in Warsaw, dated back to the thirties of the twentieth century, have been analysed. Investigations by polarised optical microscopy, scanning microscopy, powder X-ray diffraction and simultaneous thermal analysis were preformed. Based on the results obtained, it was concluded that terrazzo tiles were prepared on the basis of ordinary Portland cement and aggregate, dominated with crushed stone (marble, serpentinite, limestone and marl), accompanied by sparse quartz sand grains. The binding mass was colourised with the use of pigments containing iron ions. The occurrence of altered serpentinite and marble grains, the latter clouded and partly replaced with micrite, the presence of portlandite, indicate the terrazzo tiles were subjected to thermal impact. This is related to the fire that took place at the beginning of World War II. Based on this study, repair mortars were formulated, on one hand compatible with the authentic ones, on the other retaining traces of fire.

\section{Introduction}

As a result of the World War II, Poland was highly devastated, especially Warsaw - the capital city that was burned to the ground. War damage has affected many architectural objects, among others The Jewish Historical Institute located in the centre of Warsaw. The building of the Institute was created in the period of 1928-1936 by architect Zechariah Eber and was design for the Main Judaic Library (Małkowska 1991). After the fall of the uprising in the Warsaw ghetto on $16^{\text {th }}$ May 1943, the Great Synagogue was blown up and fire moved on to the neighbouring abode of the Main Judaic Library. As a result, the building of the library burned down, but the flooring in the main hall mostly survived from the disaster. After the World War II, the whole building was rebuilt, and the flooring made of terrazzo became a silent witness of the dramatic history (Bergman 1996). Terrazzo is a mixture similar to concrete. Portland cement is used as a binder. The filler is hard crushed-rock aggregate that are suitable for grinding and polishing. In some cases, lime-resistant pigments are added to this mixture (Mączeński 1954).

In the present work, the mortars from terrazzo floor located in the Jewish Historical Institute in Warsaw are investigated in order to characterize their mineralogical properties as well as to present the technological aspects involved in the manufacturing processes of terrazzo tiles. The decision to carry out conservation
Keywords

Terrazzo, mineralogical characterization, fire, portlandite, Portland cement

Received: 19.09.2017 Accepted: 15.10 .2017

and restoration work was taken in 2016. Thus, it was necessary to recognize the primary technology construction of the terrazzo and describe the mechanism of the damage that took place during the fire in the building. The aim of the restoration was to reconstruct the destroyed, missing parts of terrazzo flooring, and at the same time, to preserve the character of dramatic destruction from the past. One should rebuild the appearance and the atmosphere of historical decoration of the main hall, but on the other hand, stressed changes of the colour and structure of the material amended by fire. The developed reconstruction of the losses had to meet the technological requirements for the flooring in the hall used daily by staff and guests of the Institute.

\section{MATERIALS AND METHODS OF INVESTIGATION}

Described in the following article, terrazzo was composed of white and dark grey tiles of dimension 93 per $93 \mathrm{~cm}$ (Figure 1). In the central part, two parallel belts of black tiles of terrazzo emphasised the flight of stairs leading to the first floor. The terrazzo floor was prepared as a two-layered decoration. The steelreinforced ceiling was covered with a first technological layer, composed of ordinary Portland cement-based screed, containing crushed brick filler. This layer has thickness of $3.5-4.0 \mathrm{~cm}$ and is covered with finishing layer made of terrazzo, $1.5-2.0 \mathrm{~cm}$ thick.
๖ Open Access. ๑ 2018 W. Bartz, J. Martusewicz, published by De Gruyter. (c) BY-Nc-ND

This work is licensed under the Creative Commons Attribution-NonCommercial-NoDerivatives 4.0 License. 
Table 1. Sampling and macroscopic characterization of studied terrazzo.

\begin{tabular}{c|c|c}
\hline Sample: & Macroscopic description & State of preservation and the original colour \\
\hline L-1 & Grey terrazzo with white and subordinate brownish chips. & Weakly discoloured, originally grey. \\
\hline L-2 & Light-grey terrazzo with white and subordinate brownish chips. & Strongly discoloured, originally grey. \\
\hline L-3 & Black terrazzo with black-greenish and subordinate white chips. & No visible changes. \\
\hline L-5 & Brown-orange terrazzo with dark grey and subordinate white chips. & No visible changes. \\
\hline L-6 & Black terrazzo with black-greenish and subordinate white chips. & Strongly discoloured, originally black. \\
\hline
\end{tabular}

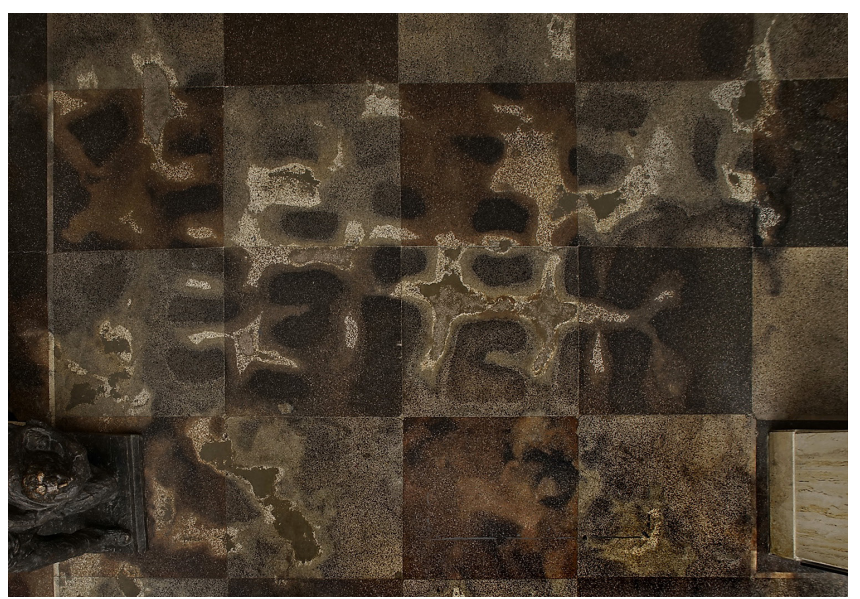

Figure 1. Terrazzo decoration with numerous discolorations, viewed from above (photographed by Grzegorza Kwolka, from the collection of the Emanuel Ringelblum Jewish Historical Institute, Warsaw).

The terrazzo floor is highly damaged, which is expressed by: 1) changes in colour leading to local heavy discolorations, and 2) structural weakness (Figure 2).

In order to fully characterize the terrazzo, sampling was performed to obtain the most representative material, but with care and attention to the valuable historic decoration. Finally, a total of 6 representative terrazzo samples were studied (Figure 2), representing different colours and stages of its preservation. All the samples were collected as $1-2 \mathrm{~cm}$ thick fragments taken from non-restored sites, with the use of a diamond microdrill. Table 1 reports the samples and their short characteristics.

Petrographic thin-sections were prepared from samples, according to the standardized technique depicted by Elsen 2006 and Blaeuer, Kueng 2007. The terrazzo samples were cut into two. The first half was intended for further instrumental analysis, while the second was impregnated and glued with epoxy-resin to a glass

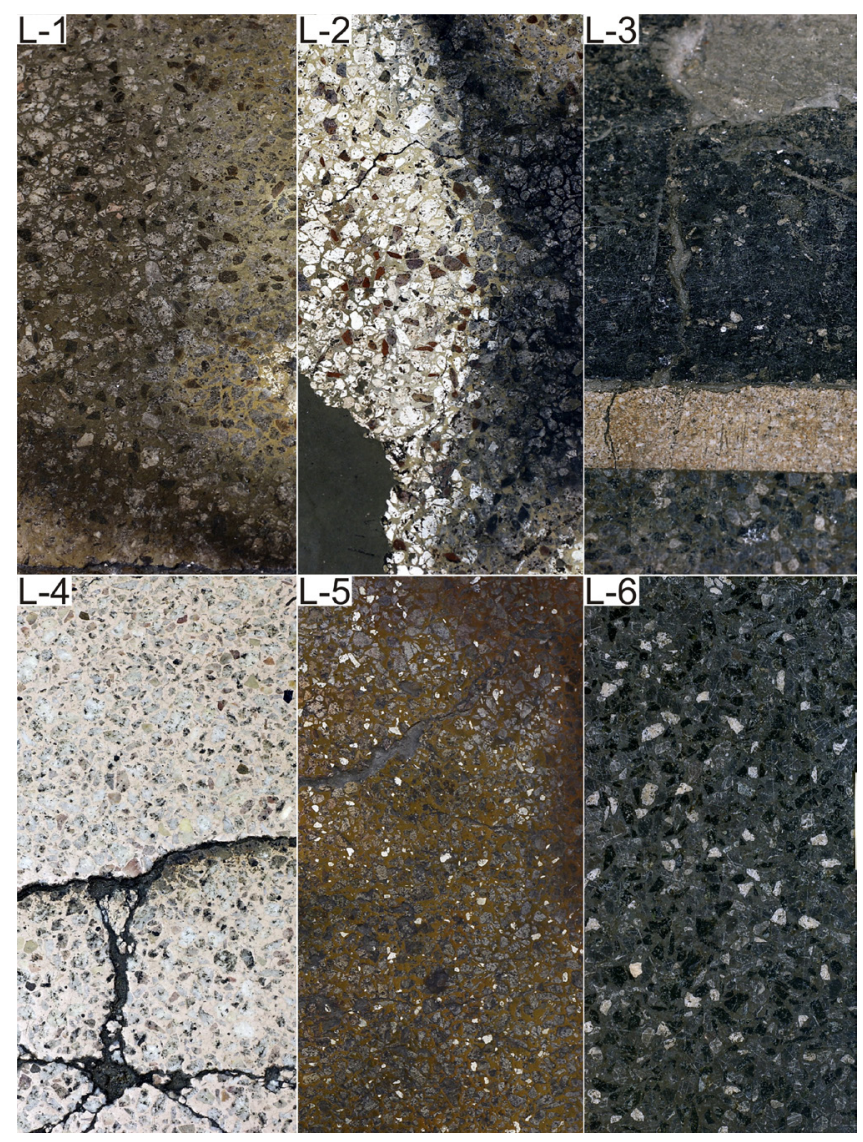

Figure 2. Analysed samples of terrazzo.

slide, polished, and covered with covering slide. Subsequently, the prepared thin-sections were analysed by means of polarizedlight optical microscopy (POM), with the use of Leica DM2500P microscope. The volume proportions of the individual components were estimated by the point-counting method, with the 
Table 2. Results of modal analysis.

\begin{tabular}{c|c|c|c|c}
\hline \multirow{2}{*}{ Sample } & \multicolumn{5}{|c}{ Modal proportion [vol \%] } \\
\cline { 2 - 5 } & Binder & Lithoclasts & Quartz & Opaque \\
\hline L-1 & 38,0 & 59,5 & 1,5 & 1,0 \\
\hline L-2 & 40,0 & 55,5 & 3,0 & 1,5 \\
\hline L-3 & 26,0 & 71,5 & 1,0 & 1,5 \\
\hline L-4 & 43,0 & 55,5 & 0,0 & 1,5 \\
\hline L-5 & 47,0 & 47,0 & 4,0 & 2,0 \\
\hline L-6 & 35,0 & 62,0 & 2,5 & 0,5 \\
\hline
\end{tabular}

use of freeware JMicroVision (Roduit, 2007). The presence of pigments was determined by means of fluorescent microscopy and microchemical reactions. The fluorescence Nikon Eclipse 50i microscope coupled with UV2A ultraviolet fluorescence filter (bandpass excitation filter: 330-380 nanometres and longpass barrier filter 420 nanometre cut-on wavelength) was used (Rudniewski 1999). Additionally, the samples were digested with hot hydrochloric acid $(3 \mathrm{M} \mathrm{HCl})$. Subsequently, the dried acid insoluble material was treated with a mixture of $3 \mathrm{M} \mathrm{HCl}$ and $\mathrm{K}_{4}\left[\mathrm{Fe}(\mathrm{CN})_{6}\right]$ for detection of $\mathrm{Fe}^{2+}$ ions, and with 2,2'-bipyridine for detection of $\mathrm{Fe}^{3+}$ ions (Minczewski, Marczenko 2005, Aleksiejew 1966).

More advanced identification of terrazzo components was performed by instrumental analysis (Middendorf et al. 2000). Samples were analysed by means of X-ray powder diffraction (XPRD, Siemens D 5005, $\mathrm{Co}_{\mathrm{ka}}$ radiation, $30 \mathrm{kV}$ and $25 \mathrm{~mA}$, in the range of $4-75^{\circ} 2 \theta$, with scanning speed $0.02^{\circ} 2 \theta / \mathrm{sec}$ ). Scanning electron microscope coupled with energy dispersive spectrometry (SEM-EDS) was applied, to obtain information on type of a binder. Analysis were performed with the use of Jeol JSM IT-100 equipped with ESD Oxford system, working under the 18-kV accelerating voltage. Additional analysis was done with the use of simultaneous thermal analysis (DSC-TG), carried out with PerkinElmer STA 6000 analyser. Scans were done in the temperature range $40-990^{\circ} \mathrm{C}$, at a heating rate of $15^{\circ} \mathrm{C} / \mathrm{min}$ and $\mathrm{N}_{2}$ purge gas (flow: $15 \mathrm{ml} / \mathrm{min}$ ).

\section{RESULTS}

\subsection{OPTICAL AND SCANNING MICROSCOPY}

The investigated terrazzo is characterized by a microcrystalline binder and a coarse-grained filler (Figure 3), which is dominated by lithic grains (lithoclasts, Table 2) of various lithology. Accessory components (Table 2) are opaques and quartz. The lithic grains consist of marble and serpentinite, while limestone and marl grains are less common, detected in samples L- 1 and L- 6 only
(Figure 3). The size of the lithoclasts is strongly variable, ranging from approximately $0.5 \mathrm{~mm}$ up to $8.0-10.0 \mathrm{~mm}$ (Figure 3). They form strongly elongated grains, whereas isometric forms are less common. All the lithoclasts are angular. The other components (i.e., quartz and opaques) form isometric to slightly elongated and rounded or subrounded grains, do not exceeding $1.0 \mathrm{~mm}$.

The occurrence of certain varieties of lithoclasts is variable. Terrazzo samples L-1 and L-2 are strongly dominated by marble grains, serpentinites do not occur (Figure 3.1, 3.2). There were few grains of microcrystalline (micritic) carbonate rocks, presumably limestones. In contrast, sample L-3 is characterized by predominance of serpentinites, whereas marble grains are sparse (Figure 3.3). Terrazzo samples L-4 and L-5 are less diversified and contain filler composed of marble or serpentinite respectively (Figure 3.4, 3.5). Sample L-6 has filler composed mainly of serpentinites, while marl and/or limestone grains are uncommon (Figure 3.6).

It should be noted that the particle size of the filler is relatively large compared to the size of thin-sections. Thus, it may result in underestimation of particular component, or even it may not be found within single thin-section.

The binding mass is microcrystalline (Figure 3), mainly composed of micritic carbonates, showing relatively high birefringence but intergrowth with microcrystalline calcium silicate hydrates (C-S-H). The presence of silicates locally lowers the birefringence of the binding mass, down to the first order. This is especially evident in terrazzo L-6 (Figure 3.6). SEM observations show that carbonates occur in the form of botryoidal aggregates or form small subhedral rhombohedrons (Figure 4.C). The calcium silicate hydrates form rod-like crystals (Figure 4.B, D), according to Ramachandran and co-authors (2002), the so-called type I C-S-H, intergrowing with carbonates. Furthermore, numerous, well preserved relics of cement clinker could be found within the binding mass. They occur as relatively small, up to $0.1-0.2 \mathrm{~mm}$ isometric aggregates, composed of colourless or yellowish crystals of dicalcium- and tricalcium silicates (C2S - belite and C3S - alite) and interstitial, brown calcium aluminoferrite (C4AF, Figure 3.2, 3.4).

A characteristic feature of the terrazzo samples is the occurrence of thermal changes, which mostly affected marble lithoclasts. Part 

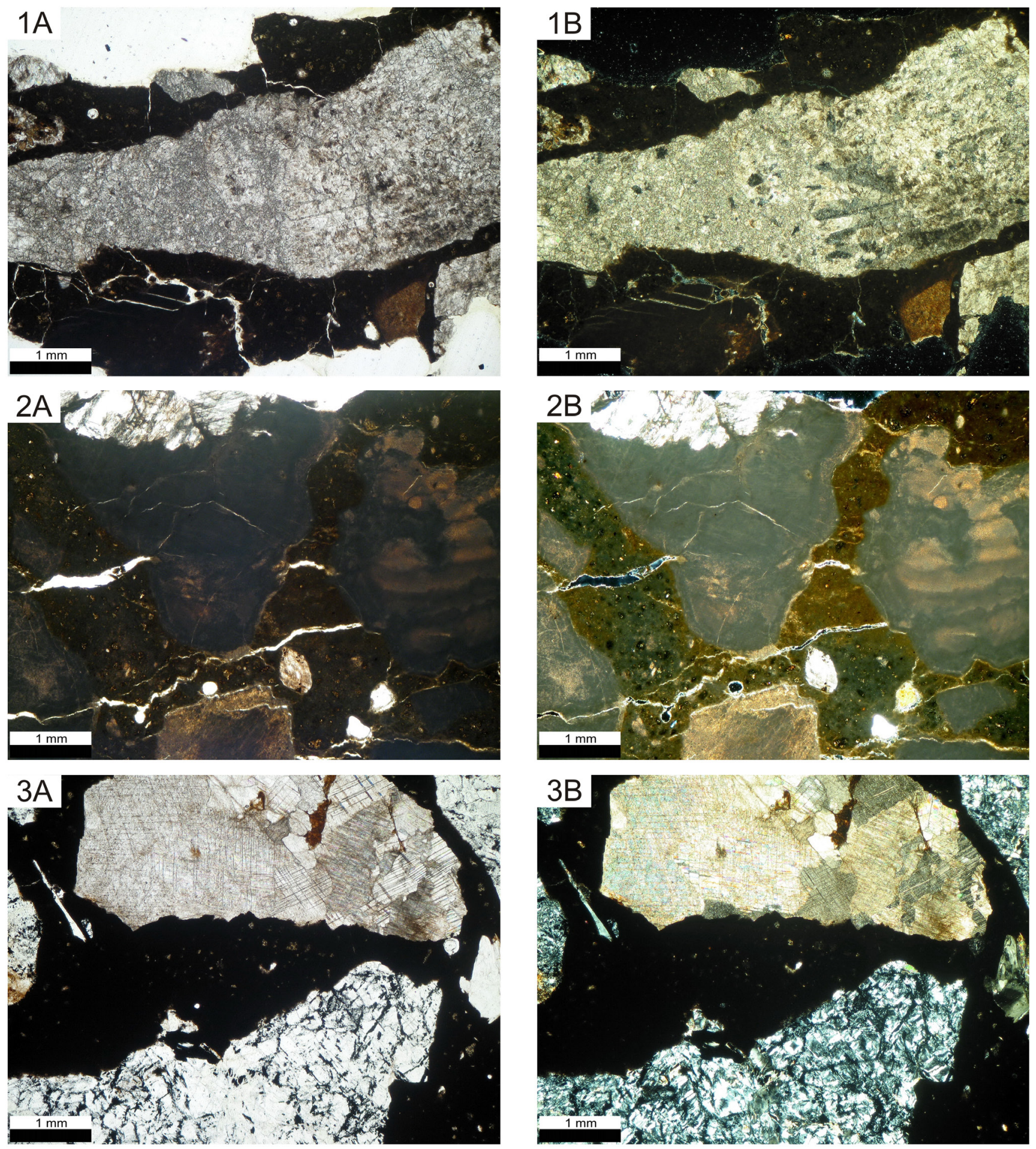

Figure 3. Petrographic thin-sections of terrazzo viewed in plane-polarized (A) and cross-polarized light (B). 

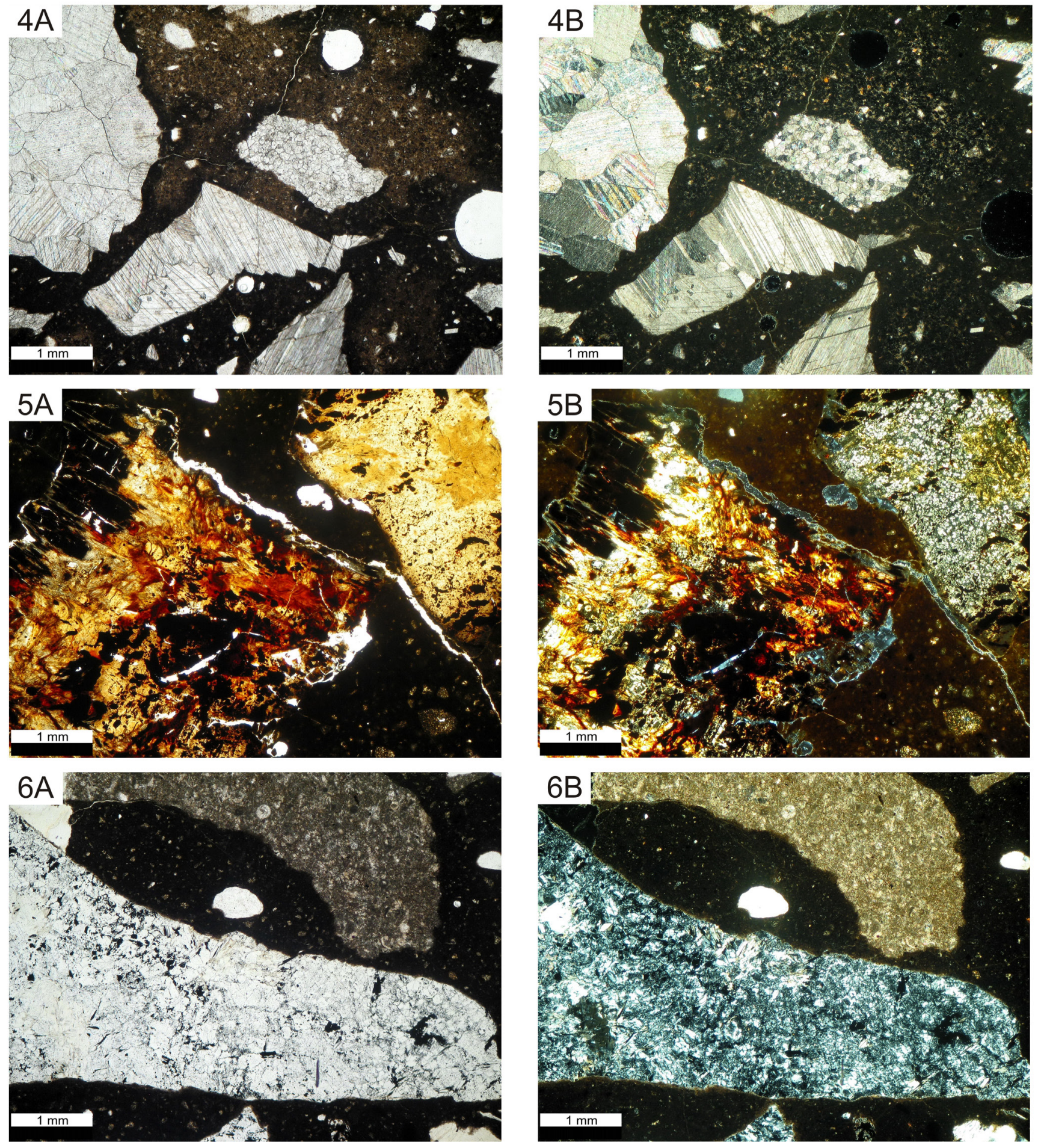

Figure 3 (continued). Petrographic thin-sections of terrazzo viewed in plane-polarized (A) and cross-polarized light (B). 

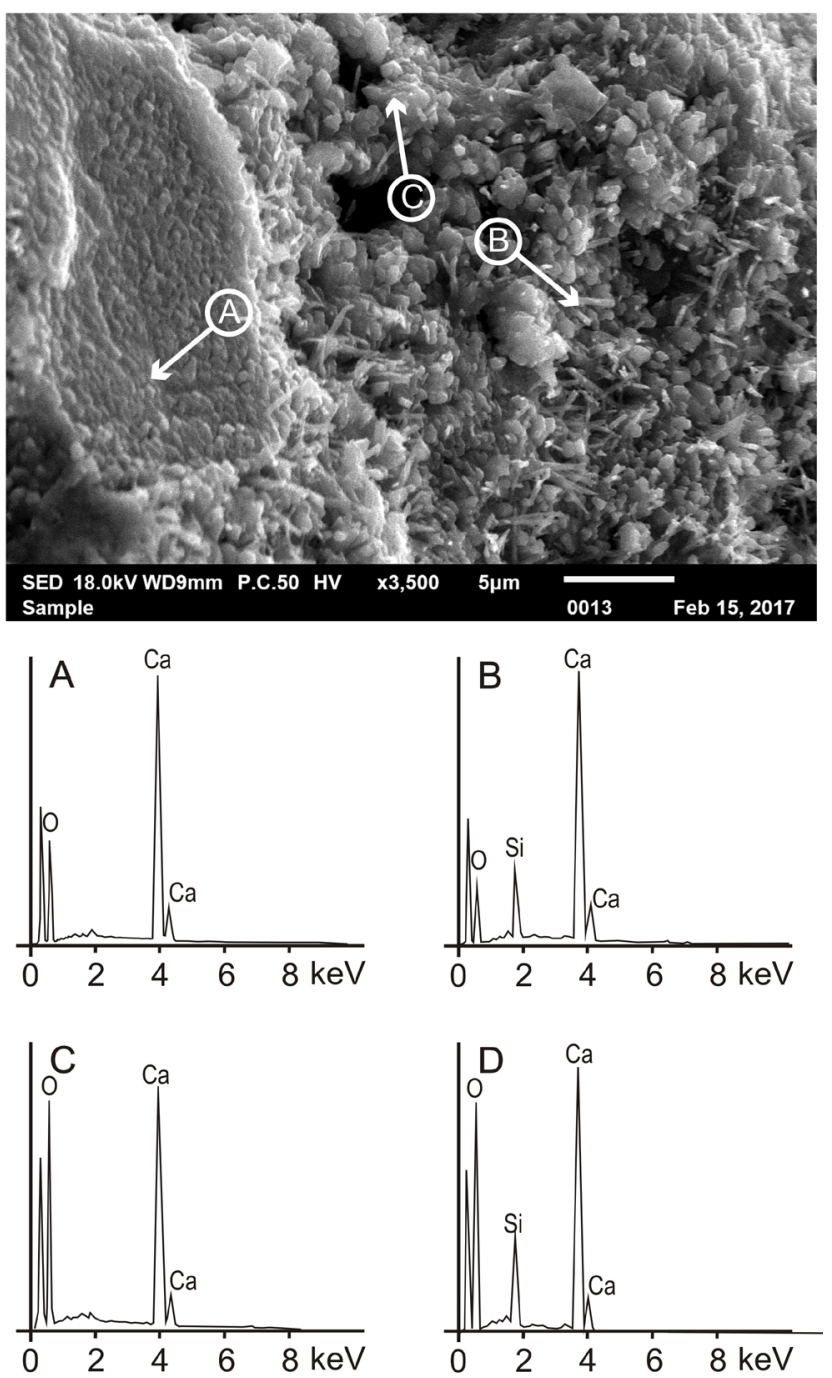

Figure 4. SEM image and representative EDS spectra of sample L-1.

of the marbles is unchanged and has the typical appearance of the unaltered rocks (Figure 3.1, 3.3. 3.4). Quite the opposite is the case of terrazzo L-2 (Figure 3.2). Carbonate crystals - principal components of marbles, are partly replaced by brownish micrite, which mimics the primordial crystalline structure of the rock. Additionally, less changed crystals with cloudy appearance also occur.

\subsection{MICROCHEMICAL ANALYSIS AND FLUORESCENT MICROSCOPY}

Microchemical analysis and fluorescent microscopy were applied for representative samples of terrazzo, having different colour (L-2, L-3 L4, L-6, c.f. Table 1). Except for the sample L-3, the others show weak fluorescence of binding mass (Figure 5), pointing out the presence of iron containing phases. Moreover, all the ter-

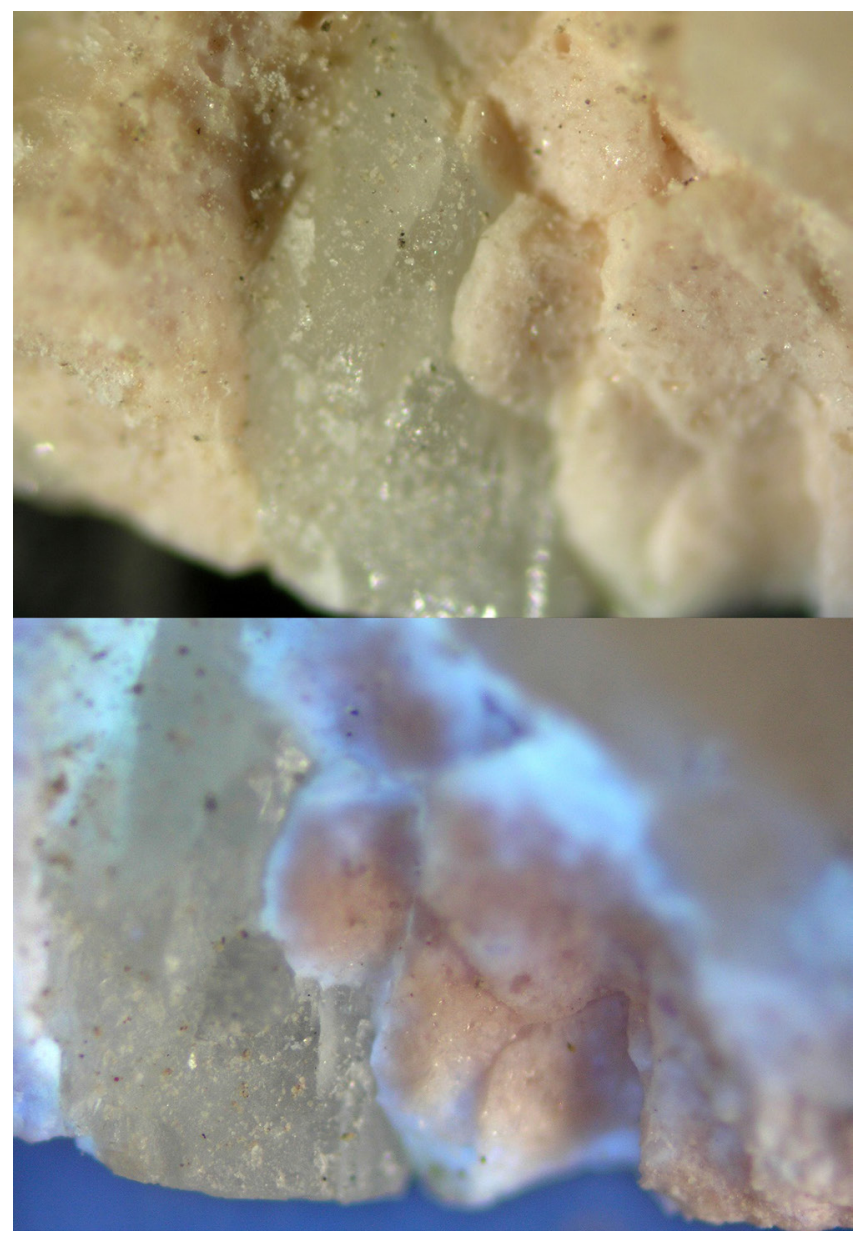

Figure 5. Ultraviolet fluorescence of terrazzo sample L-4.

razzo samples show positive reaction to $3 \mathrm{M} \mathrm{HCl}$ and $\mathrm{K}_{4}\left[\mathrm{Fe}(\mathrm{CN})_{6}\right]$ manifested in the occurrence of newly formed Prussian blue $\mathrm{Fe}_{4}\left[\mathrm{Fe}(\mathrm{CN})_{6}\right]_{3}$. After the treatment of 2,2'-bipyridine, pink colour appeared. Both positive reactions point out that there is a presence of iron ions, with the oxidation number of +3 and +2 , respectively.

\subsection{X-RAY POWDER DIFFRACTION}

The X-ray powder diffraction patterns show that calcite is the most common crystalline phase in all terrazzo samples (Figure 6, 7), with its most intense peak at $d=3.03 \AA(I=100)$. Another carbonate phase is dolomite, recognized by less intense $2.88 \AA$ peak and found in samples L-1, L-3, L-5 and L- 6 (Figure 6, 7). Calcite as well as dolomite are typical constituents for dolomitic marbles. Additionally, XRPD results of all the terrazzo samples show the presence of quartz, with its most intense peak at $d=3.34 \AA$. All samples show the presence of peaks at $d=2.77,2.25 \AA$ (Figure 6, 7), typical for a poorly-crystalline calcium silicate hydrate (C-S-H), 


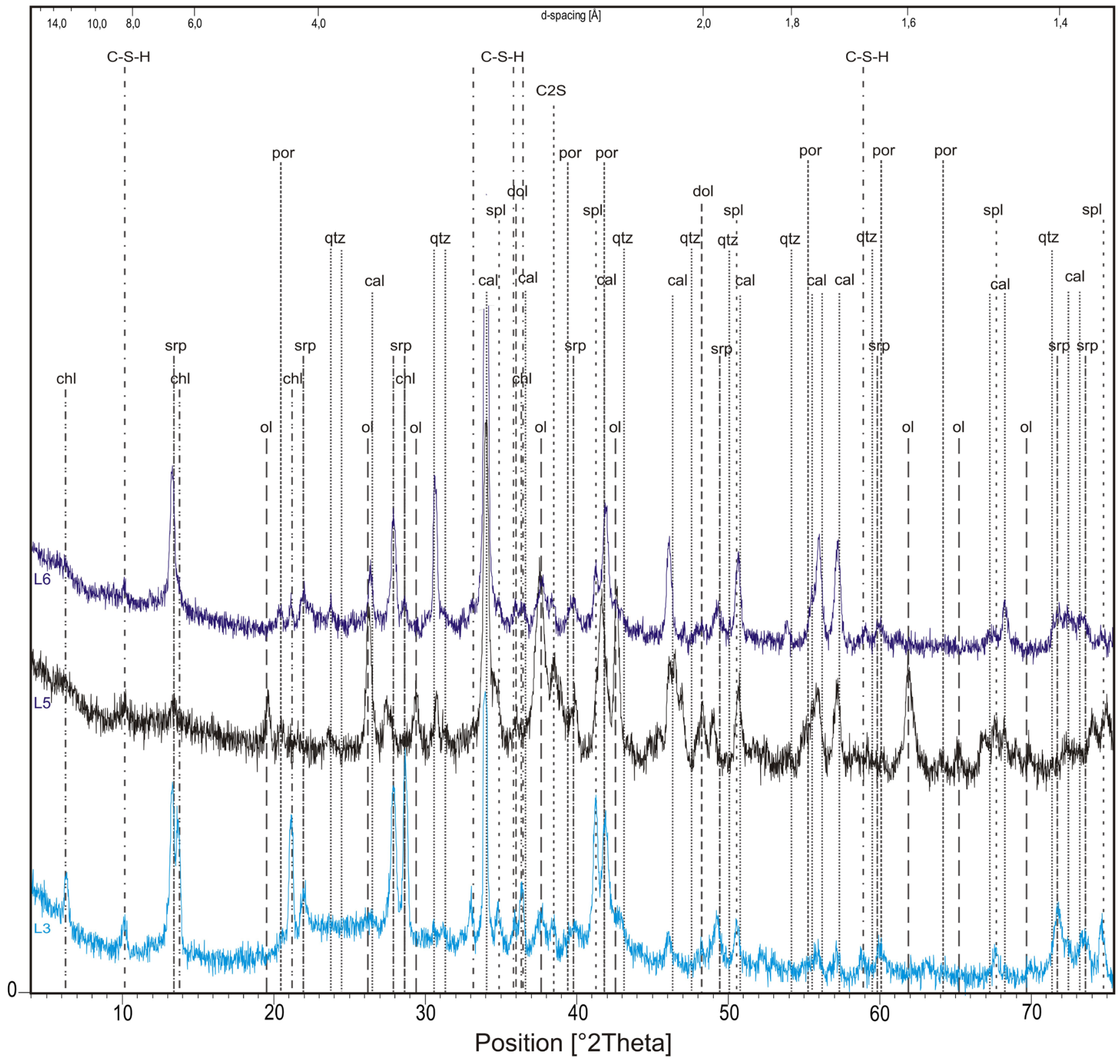

Figure 6. XRPD patterns of terrazzo samples: $L-3, L-5, L-6$.

a hydration product of ordinary Portland cement. The next phase associated with the latter one, being its main component, is dicalcium silicate (C2S), represented by peak of relatively low intensity, found at $d=2.79 \AA$.

Serpentine minerals (chrysotile and/or antigorite) were mainly detected in samples L-3 and L-6 (Figure 6). Their most intense peak occurs at $d=7.28$ A. The small peak at this particular position suggests its occurrence in sample L-5 as well, but in very small quantities. The powder diffraction studies revealed that samples L-3, L-5 and L- 6 contain olivine and chlorites, identified by their most intense peaks at $d=2.46 \AA$ and at $d=7.07 \AA$, respec- tively. The relative intensity of their most intense peaks suggests that the olivine is common phase for sample L-5, whereas chlorites occur primarily in samples L-3 and L-6 (Figure 6). Since XPRD pattern of samples $L-1, L-2$, reveal the presence of less intense peak at $d=2.46 \AA$, they may contain small amounts of olivine too (Figure 6). A well define peak at $2.52 \AA$ is visible on patterns collected for samples L-3, L-5 and L-6 (Figure 6). It may correspond to spinel phase (chromite or magnetite). All these mineral phases are characteristic for serpentinites. Additionally, a peak at $2.63 \AA$, relatively strong and well visible on pattern $L-2$ and less intense on pattern L-4 is attributed to portlandite (Figure 6, 7). 


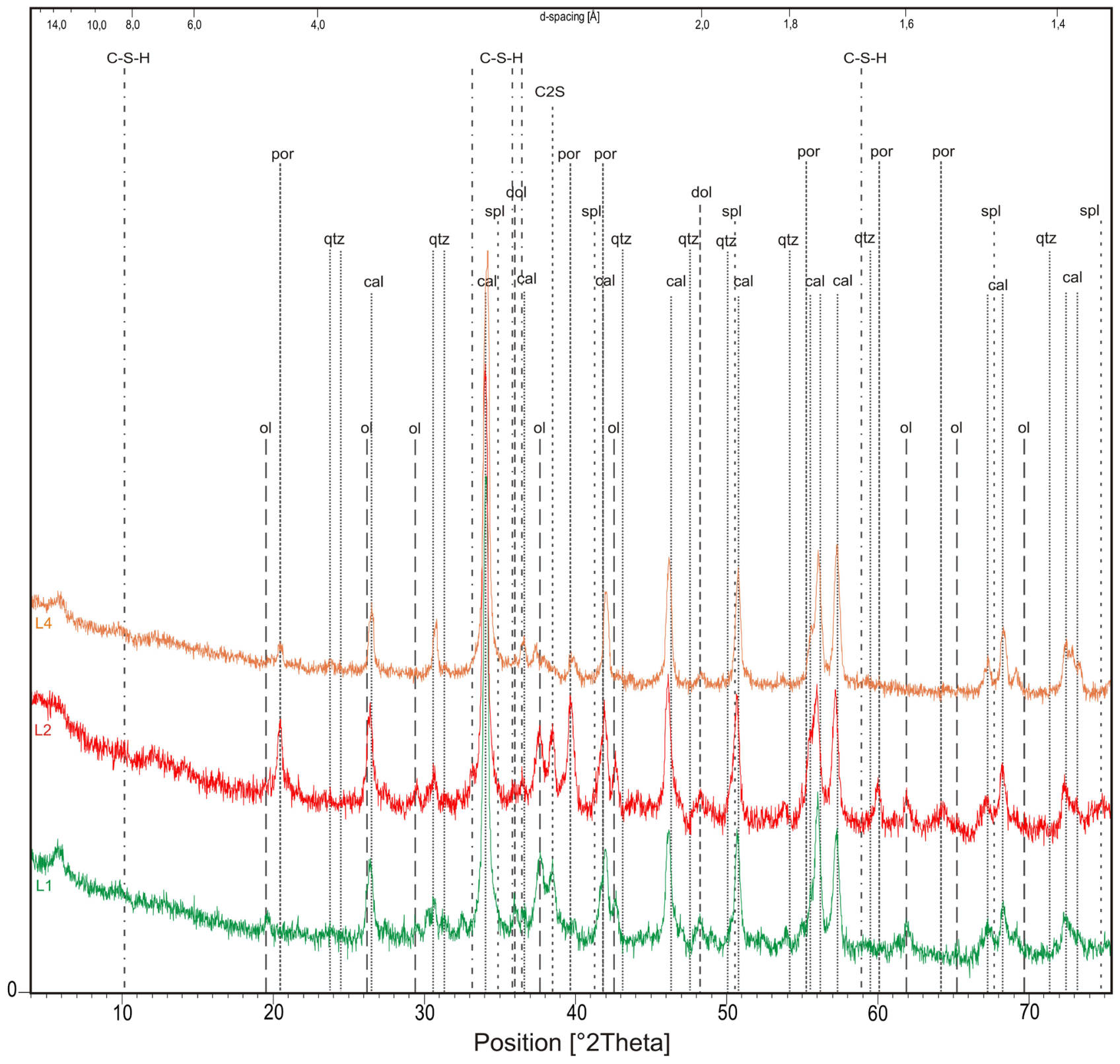

Figure 7. XRPD patterns of terrazzo samples: $L-1, L-2, L-4$.

\subsection{THERMAL ANALYSIS}

All the DSC-TG patterns (Figure 8) show a relatively broad derivative weight peak (DTG) at approximately $100^{\circ} \mathrm{C}$, indicating a weight loss due to release of absorbed water. It corresponds to the endothermic peak in the temperature range from 72 to $79^{\circ} \mathrm{C}$. After exceeding the temperature $100^{\circ} \mathrm{C}$, a constant weight-loss is still observed. A small inflection or less frequently two small inflections on derivative heat flow curve (DDSC) occurs in the temperature range from 105 to $135^{\circ} \mathrm{C}$ (Figure 8). Several miner- als, like gypsum or clay minerals dehydrate in this temperature range (Wyrwicki 1988, Földvári 2011). However, it is more likely that a calcium-silicate-hydrate phase (C-S-H), typical hydration product of ordinary Portland cement in a mature concrete paste underwent decomposition, since its dehydration peaks usually occur at temperatures in the range of $115-125^{\circ} \mathrm{C}$ (Sha et al. 1999, Bruno et al. 2004, Ramachandran et al. 2002). The DDSC curve of sample L-2 (Figure 8B) shows two endothermic peaks at 362 and $460^{\circ} \mathrm{C}$, corresponding perfectly to those observed on DTG curve, at 381 and $471^{\circ} \mathrm{C}$ respectively. The second DTG and DDSC peak 

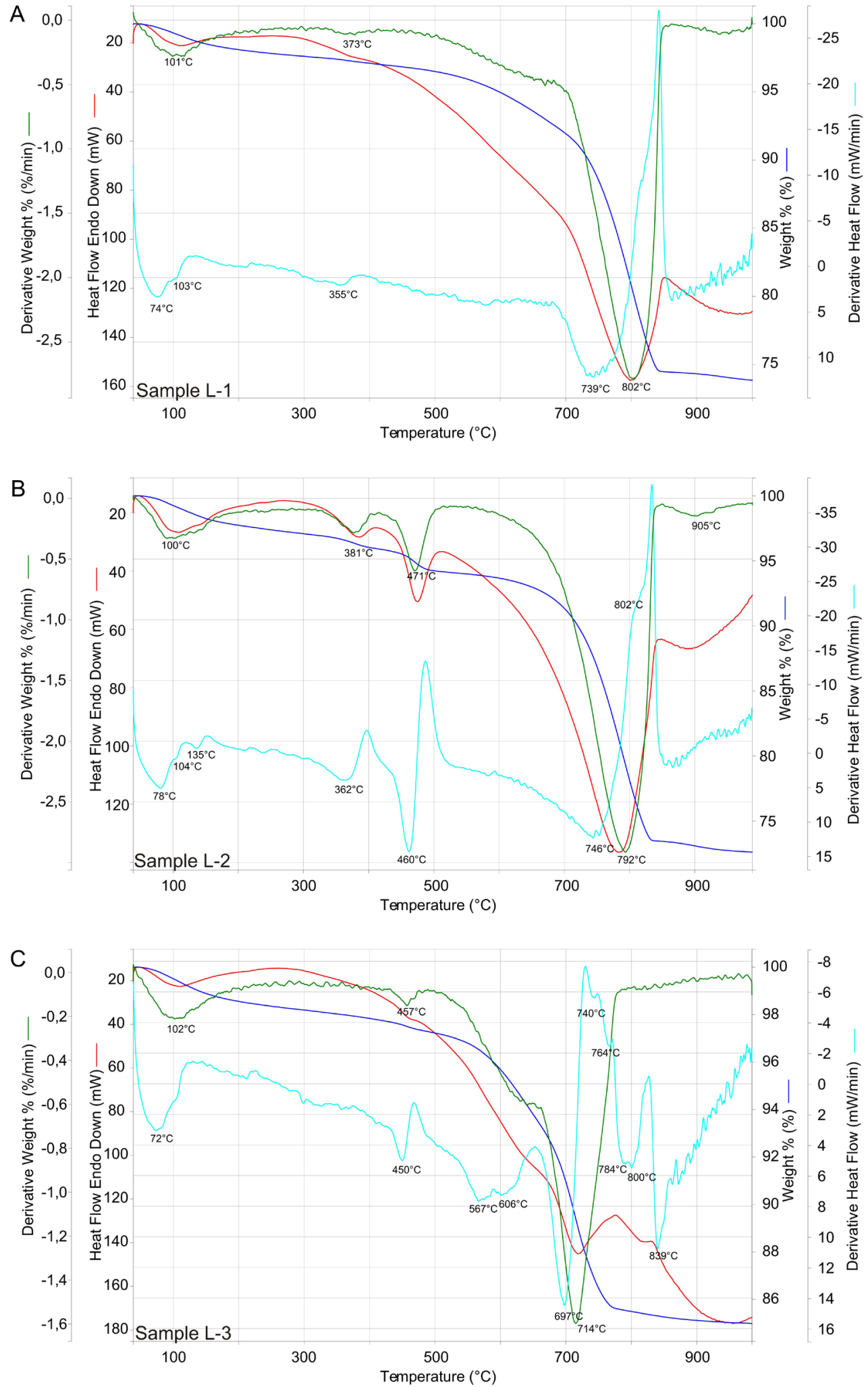

Figure 8. DSC-TG curves of investigated terrazzo samples. 

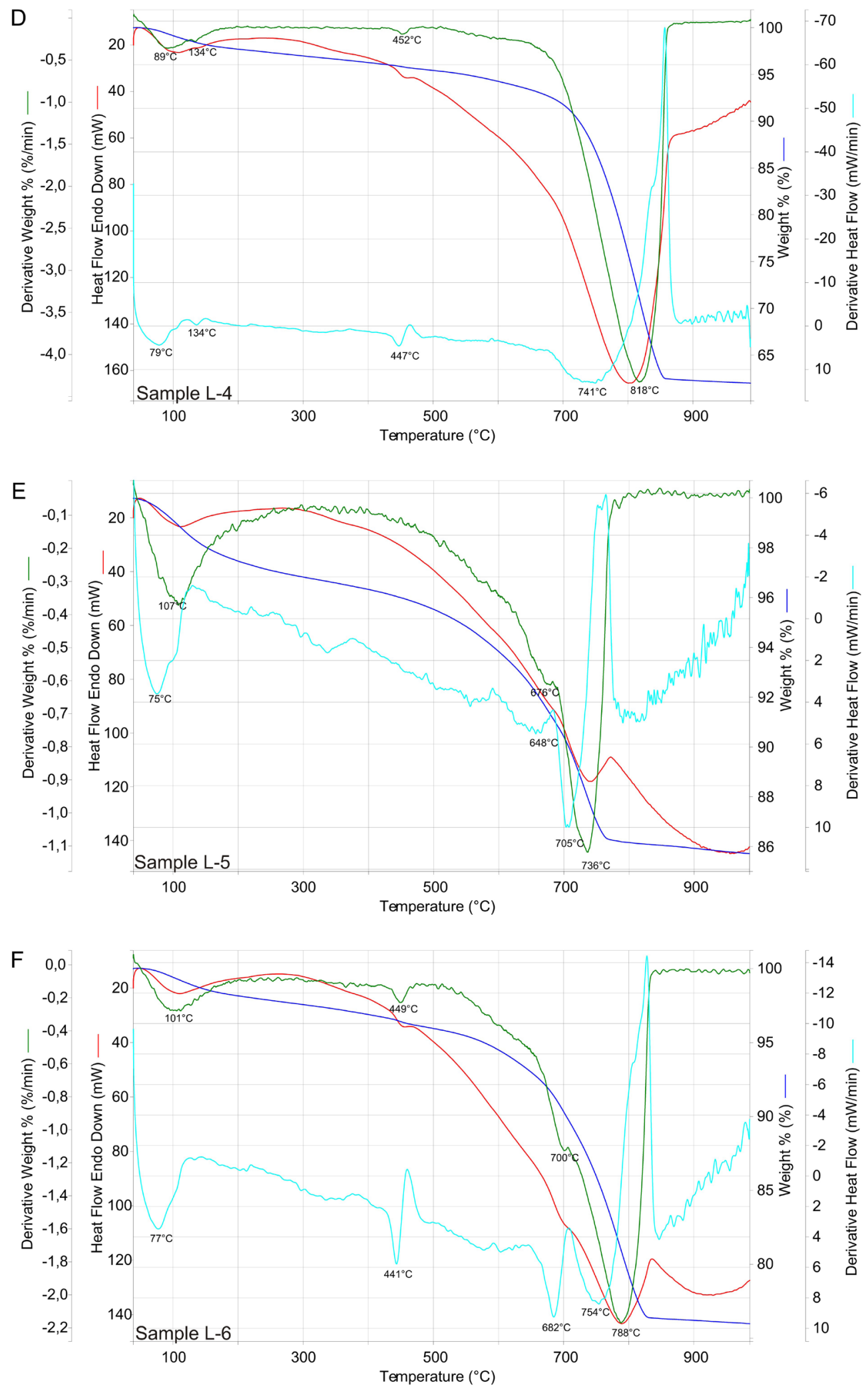

Figure 8 (continued). DSC-TG curves of investigated terrazzo samples. 
is attributed to portlandite $\left(\mathrm{Ca}(\mathrm{OH})_{2}\right)$, which dehydrates between 450 and $550^{\circ} \mathrm{C}$ (around $460^{\circ} \mathrm{C}$ in our case; Ramachandran et al. 2002, Földvári 2011). Smaller endothermic peaks were also found in DDSC and DTG curves for samples L-3, L-4, L-6 (Figure 8C, D, F). The aforementioned peak at $381^{\circ} \mathrm{C}$ corresponds well to the temperature of brucite $\left(\mathrm{Mg}(\mathrm{OH})_{2}\right)$ dehydration, which typically dissociates in the temperature range $350-450^{\circ} \mathrm{C}$ (Ramachandran et al. 2002, Földvári 2011). A small broad peak at $355^{\circ} \mathrm{C}$, on DDSC curve of sample L-1, accompanied by slight weight loss centred at $373^{\circ} \mathrm{C}$, could also be attributed to decomposition of magnesium hydroxide. The first major endothermic reaction, accompanied by a very strong weight loss, takes place in the c.a. $700-800^{\circ} \mathrm{C}$ temperature range. It should be assigned to decomposition of the carbonate phase - calcite $\left(\mathrm{CaCO}_{3}\right)$, connected with $\mathrm{CO}_{2}$ release (Wyrwicki 1988, Földvári 2011). A single step endothermic reaction characterises the samples L-1, L-2 and L-4 (Figure 8A, B, D), whereas in case of samples L-3, L-5 and L-6, an additional and weak DTG peak at c.a. $650-700^{\circ} \mathrm{C}$ was observed (Figure 8C, E, F). Together with the endothermic peak attributed to dissociation of calcite, it suggests the presence of dolomite $\left(\mathrm{CaMg}\left(\mathrm{CO}_{3}\right)_{2}\right)$. A distinctive doublet occurs during its thermal dissociation, caused by double stage decomposition of this phase (Wyrwicki 1988, Földvári 2011). According to Wyrwicki (1988) and Földvári (2011), the first and the second reaction takes place in higher temperatures, comparing to our observations. This difference may explain the much lower sample weight (tens of $\mathrm{mg}$ ) analysed by means of DSC-TG, comparing to weight (hundreds of $\mathrm{mg}$ ) in case of quoted DTA-TG results (op. cit.).

There are two additional small endothermic peaks, at 740 and $764^{\circ} \mathrm{C}$ for sample L-3 (Figure $8 \mathrm{C}$ ), mostly related to dehydroxylation of serpentine minerals (antigorite, chrysotile and lizardite; Földvári 2011). Since they dehydroxylate at different temperatures, it is difficult to match the exact mineral. Nevertheless, the latter of the three aforementioned serpentine-group members should be excluded, since it dehydroxylates in much lower temperature (below $650^{\circ} \mathrm{C}$ ). One weight loss accompanied with small endotherm was not clearly identified, but well visible for samples $\mathrm{L}-1$ and $\mathrm{L}-2$ in the $850-950^{\circ} \mathrm{C}$ temperature range (Figure $8 \mathrm{~A}, \mathrm{~B}$ ). This weight loss could be related to the presence of halides. For example, halite $(\mathrm{NaCl})$ experience melting and then evaporation above the temperature $800^{\circ} \mathrm{C}$ (Földvári 2011).

\section{DISCUSSION}

Our mineralogical studies showed that terrazzo samples were prepared on the basis of ordinary Portland cement and dyed in order to obtain the desired colour effect. Coarse-grained filler was applied, composed mainly of crushed stone, with subordinate quartz grains. The latter, occurring as well-rounded grains, probably represents the quartz sand and plays the role of an accidental component. Crushed stone is mostly represented by marble (composed of calcite and dolomite) and serpentinite (composed of minerals belonging to the serpentinite group and olivive); whereas, limestone is a subordinate part of the filler.

The binder of terrazzo floor is a microcrystalline mass, composed of micrite and the hydration products of ordinary Portland cement. The binding mass is dyed with pigments to attain colour effect. Microchemical analysis and fluorescent microscopy revealed that pigments containing iron ions were utilized. They were red ochre pigment (so-called Mars red), composed of hematite and iron black pigment composed of magnetite (so-called Mars black; Eastaugh et al. 2004). The X-ray diffraction analysis confirmed the presence of magnetite, while hematite was not detected. It is presumably due to relatively low concentration of this phase, below the detection limit of PXRD method, or its weak crystallinity.

A characteristic feature of a few terrazzo samples is the presence of grains of carbonate rocks, clouded or partly replaced by secondary micrite. Such grains registered thermal impact of fire, started during the blowing up of the synagogue by the German troops in 1943 (Małkowska 1991). As a result of relatively long thermal impact, part of carbonatic lithoclasts of terrazzo underwent calcination and transformed into calcium oxide (i.e., quick lime). Subsequently, reacting with moisture, it transformed into calcium hydroxide (portlandite), a main component of a hydrated lime. Afterwards, the latter one was reacting with atmospheric carbon dioxide to form calcium carbonate (calcite). Although one of the early products of the hydration process of ordinary Portland cement is also portlandite, it is immediately subjected to carbonation, ultimately leading to the formation of calcium carbonate (Ramachandran et al. 2002). We must bear in mind that the terrazzo thickness is relatively low; thus, we expect that all the portlandite, originally formed during setting of ordinary Portland cement, underwent complete carbonation. Experimental researches showed, that the extent of carbonation is maximum at the surface up to the depth of $40 \mathrm{~mm}$ (Ramachandran et al. 2002), much thicker in comparison to the thickness of our terrazzo tiles. Unequivocal evidence for generation of portlandite due to fire are changes detected in the structure of marble grains, observed in a few terrazzo samples. Moreover, there is a direct correlation between the intensity of marble alterations and the intensity of portlandite peaks on PXRD patterns. The same positive correlation is well documented concerning the obtained results from thermal analysis.

The presence of heavily altered grains of marble aggregate indicates that thermal impact was relatively long, with the temperature exceeding $600^{\circ} \mathrm{C}$, marking the beginning of thermal dissociation of calcite. (Földvári 2011). Almost completely altered marble grains are the most abundant in terrazzo sample L2. Thus, this sample underwent the most intense thermal changes. Much weaker changes are registered by the sample L1, containing marble grains composed of only slightly clouded carbonate crystals, pointing out to the weakly advanced calcination. In the case of the samples L3, L4 and L6, the marble grains are fresh, with no 


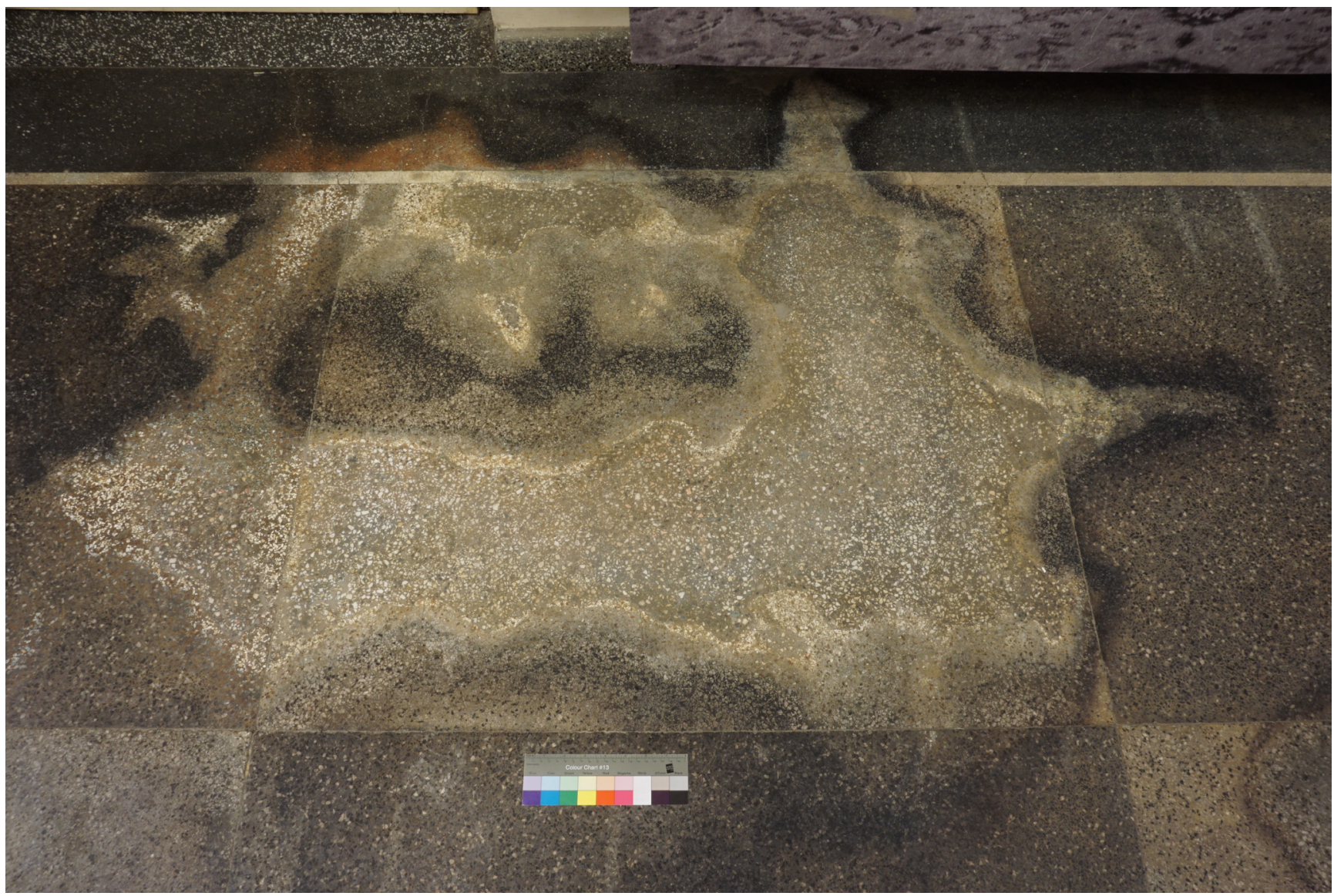

Figure 9. The terrazzo floor after conservation (from the collection of the Emanuel Ringelblum Jewish Historical Institute, Warsaw).

signs of thermal impact; thus, we conclude that they are weakly thermally altered. Since the sample L5 does not contain marble filler, it is hard to assess the impact of fire. On the other hand, serpentinite filler is discoloured from the typical black-green colour into a brownish colour, pointing to the possible thermal influence.

It is possible that the binding mass of terrazzo tiles was subjected to thermal changes too; however, its microcrystalline mass does not provide direct evidence of the impact of fire. On the other hand, terrazzo samples with heavily changed filler grains have strongly cracked binding mass. Therefore, it can also be linked with the impact of fire.

\section{FINAL REMARKS}

The result of our petrographic investigation allowed us to fully characterise the composition of the terrazzo tiles. Furthermore, it was a base for preparing the recipe of the fillings, based on mineral mortars containing ordinary Portland cement and carefully se- lected and sieved crushed stone filler (marble). At the same time, the old putties made of grey ordinary Portland cement and epoxy resin were removed. Several tests were conducted to develop the best solution for filing the losses in the terrazzo floor. The structure and the colour imitated the destroyed parts of the terrazzo in the nearby (Figure 9). The parts of the floor, discoloured, cracked and delaminated, were consolidated by reinforcing injections of mortar based on natural limes free from efflorescing salts.

\section{Acknowledgements:}

The authors would like to thank Anna Nowicka from the Faculty of Conservation and Restoration of Works of Art of the Academy of Fine Arts in Warsaw for pigment analyses. 


\section{REFERENCES}

[1] Aleksiejew W. N. (1966). Analiza jakościowa, Wydawnictwo Naukowe PWN, Warszawa 1966.

[2] Blaeuer C., Kueng A. (2007). Examples of microscopic analysis of historic mortars by means of polarizing light microscopy of dispersion and thin sections. Materials characterization 58: 1199-1207.

[3] Bergman E. (1996). Dzieje budynku ŻıH [in:] Żydowski Instytut Historyczny. 50 lat działalności. Materiały z konferencji jubileuszowej, Warszawa 1996.

[4] Bruno P., Calabrese D., Di Pierro M., Genga A., Laganara C., Manigrassi D.A.P., Traini A., Ubbrìaco P. (2004). Chemical-physical and mineralogical investigation on ancient mortars from the archaeological site of Monte Sannace (Bari-Southern Italy). Thermochimica Acta 418: 131-141.

[5] Eastaugh, N., Walsh, V., Chaplin, T., Siddall, R. (2004). The Pigment Compendium: A Dictionary of Historical Pigments. Elsevier - Butterworth Heinemen, 499 pp.

[6] Elsen J. (2006). Microscopy of historic mortars - a review. Cement and Concrete Research 36: 1416-1424.

[7] Földvári, M. (2011). Handbook of thermogravimetric system of minerals and its use in geological practice. Geological Institute of Hungary, Budapest.

[8] Małkowska E. (1991). Synagoga na Tłomackiem, Warszawa 1991.

[9] Mączeński Z. (1954). Poradnik budowlany dla architektów, Warszawa 1954.
[10] Middendorf B., Baronio G., Callebaut K., Hughes J.J. (2000): Chemicalmineralogical and physical-mechanical investigations of old mortars. [In] Proceedings of the International RILEM-workshop "Historic mortars: characteristics and tests" (P. Bartos, C. Groot and J. J. Hughes, eds.), Paisley, 53-59.

[11] Minczewski J., Marczenko Z. (2005). Chemia analityczna, Tom 1, Wydawnictwo Naukowe PWN, Warszawa 2005.

[12] Ramachandran V.S., Paroli R.M., Beaudoin J.J., Delgado A. H. (2002). Handbook of thermal analysis of construction materials, Noyes Publications, Norwich, New York, U.S.A.

[13] Roduit, N. (2007). JMicroVision: un logiciel d'analyse d'images pétrographiques polyvalent. http://www.jmicrovision.com (on-line, accessed: January 2017).

[14] Rudniewski P. (1999). Pigmenty i ich identyfikacja. Skrypty Dydaktyczne ASP w Warszawie, Warszawa 1999.

[15] Sha W., O'Neill E.A., Guo Z. (1999). Differential scanning calorimetry study of ordinary Portland cement. Cement and Concrete Research 29: 1487-1489.

[16] Wyrwicki R. (1988). Analiza derywatograficzna skał ilastych, Wydawnictwo Uniwersytetu Warszawskiego, Warszawa 1988. 